\title{
New Diarylheptanoid from Garuga pinnata Roxb
}

\author{
Mst. Taslima Khatun ${ }^{1}$, M. Mahboob Ali Siddiqi ${ }^{2}$, Al-Mansur M. A. ${ }^{3}$, M. H. Sohrab ${ }^{3}$, A. F. M. Mustafizur Rahman ${ }^{1}$, \\ Choudhury M. Hasan ${ }^{4}$ and A. M. Sarwaruddin Chowdhury*1 \\ ${ }^{1}$ Department of Applied Chemistry and Chemical Engineering, Dhaka University, Dhaka-1000, Bangladesh \\ ${ }^{2}$ Institute of Natural Sciences, United International University, Dhaka-1209, Bangladesh \\ ${ }^{3}$ Analytical Research Division, Bangladesh Council of Scientific and Industrial Research, Dhaka-1205, Bangladesh \\ ${ }^{4}$ Department of Pharmaceutical Chemistry, Dhaka University, Dhaka-1000, Bangladesh.
}

(Received : 10 August 2011; Accepted : 10 March 2013)

\begin{abstract}
9'-Desmethylgaruganin I has been isolated from the dichloromethane extract of the stem bark of Garuga pinnata Roxb. The crude extract was screened for antimicrobial activity against a wide range of gram-positive and gram-negative bacteria and fungi by disc diffusion method and cytotoxicity by brine shrimp lethality bioassay. The dichloromethane extract showed moderate inhibitory activity to microbial growth and weak cytotoxicity having $\mathrm{LC}_{90} 25.703 \mu \mathrm{g}-\mathrm{mL}^{-1}$.
\end{abstract}

Key words: Garuga pinnata, Brine shrimp lethality bioassay, Antimicrobial activity, 9'-Desmethylgaruganin I.

\section{Introduction}

Garuga pinnata (Bengali name- Kharapata, kapila; Family-Burseraceae), a tree with very large pubescent compound panicles and black drupes, grows mainly in the hilly districts and semi evergreen forests of Bangladesh, India, Malaysia and the Philippines. ${ }^{1,2}$ Furthermore, it is found from previous researches that leaf juice and stem juice are used for the treatment of asthma ${ }^{1,3}$ and in curing opacities of the conjunctiva, respectively. In addition, decoction of the roots is used in the treatment of pulmonary affections while fruit acts as a stomachic and expectorant. ${ }^{1,4}$ Moreover, leaves and stem bark led the isolation of amentoflavone ${ }^{5}$, steroids, terpenes, alkaloids, flavanoids, saponins ${ }^{1}$, euphane triterpene alcohol ${ }^{6}$, three macrocyclic diarylheptanoids ${ }^{7}$ (6'-hydroxygaruganin V, 9'-desmethylgarugamblin I, and 1,9'-didesmethylgaruganin III). This paper deals with the isolation and characterization of 9'desmethylgaruganin I from the dichloromethane extract of dried powdered stem bark and preliminary antimicrobial and cytotoxicity activities of different organic extractives of extracts of Garuga pinnata.

\section{Materials and Methods}

\section{General experimental procedure}

The ${ }^{1} \mathrm{H}$ NMR spectrum was recorded using a Bruker AMX$400(400 \mathrm{MHz})$ instrument. For NMR studies deuterated chloroform was used and the $\delta$ values for ${ }^{1} \mathrm{H}$ spectra were referred to the residual non-deuterated solvent signals.

\section{Plant materials}

Fresh stem bark of Garuga pinnata was collected from Chittagong in the month of August, 2006. It was identified by Bangladesh National Herbarium, Dhaka (DACB30734). The barks were cut into small pieces and air dried for several days. The pieces were then dried in oven for 24 hours at $40{ }^{\circ} \mathrm{C}$ for better grinding. Finally, the dried crispy bark was ground into a coarse powder using a grinding machine.

\section{Extraction and Isolation}

The air dried powdered stem bark (500 g) of Garuga pinnata was successively extracted for 7 days with petroleum ether, dichloromethane and methanol through hot extraction process with the help of Soxhlet apparatus at considerably low temperature $\left(40-50{ }^{\circ} \mathrm{C}\right)$. The extracts were filtered through Whatman No.1 filter paper. The volume of the filtrates was reduced using a Buchii rotary evaporator at low temperature and pressure and consequently petroleum ether, dichloromethane and methanol extracts were obtained. Among the three extracts, the dichloromethane soluble fraction $(0.81 \mathrm{~g})$ was fractionated by column chromatography (CC) over silica gel (70-230 mesh) using petroleum ether, followed by mixtures of petroleum ether and chloroform, then by chloroform and finally chloroform and methanol mixtures of increasing polarities to give 25 fractions, collecting 100 $\mathrm{mL}$ in each.

Thin layer chromatography (TLC) screening of the fractions 11-13 revealed the presence of identical spots on TLC plate and thus, these three combined fractions were subjected to preparative thin layer chromatography (stationary phase- silica gel $\mathrm{F}_{254}$, mobile phase- $n$-hexane: ethyl acetate [40:60] with 3 drops of acetic acid, thickness of plate $-0.25 \mathrm{~mm}$ ). From the developed plate, a band was observed with $R_{f}$ value of 0.38 under UV lamp at $254 \mathrm{~nm}$ and thus scrapped off and initially eluted with a mixture of chloroform and ethyl acetate followed by $100 \%$ ethyl acetate. Evaporation of solvent afforded a white gum-like mass, which was then subjected to ${ }^{1} \mathrm{H}$ NMR spectroscopy to check its purity. The ${ }^{1} \mathrm{H}$ NMR spectrum revealed that the

*Author for Correspondence,e-mail: sarwar@du.ac.bd 
substance was in the pure form and the substance was recognized as 9'-desmethylgaruganin I (Fig.1).

On the other hand, Fraction-3, Fraction- 4 and Fraction-8 showed concentrated spots on TLC plate during TLC screening. Furthermore, all these three fractions showed sharp tailing on TLC plates with different solvent systems and seemed difficult to isolate the components from each fraction. Thus, phytochemical investigations of these three fractions were avoided but investigations for antimicrobial activity and cytotoxicity were conducted for each fraction.

\section{9'-Desmethylgaruganin I}

White gum; ${ }^{1} \mathrm{H}$ NMR (400 MHz, $\left.\mathrm{CDCl}_{3}\right): \delta 3.75(3 \mathrm{H}, \mathrm{s}$, $\left.\mathrm{OCH}_{3}-1\right), 6.50(1 \mathrm{H}, \mathrm{s}, \mathrm{H}-2), 3.95\left(3 \mathrm{H}, \mathrm{s}, \mathrm{OCH}_{3}-3\right), 5.63$ $(1 \mathrm{H}, \mathrm{s}, \mathrm{H}-5), 2.34(2 \mathrm{H}, \mathrm{m}, \mathrm{H}-7), 2.86(2 \mathrm{H}, \mathrm{m}, \mathrm{H}-8), 4.94$ $(1 \mathrm{H}, \mathrm{s}, \mathrm{H}-10), 6.97\left(2 \mathrm{H}, \mathrm{d}, J=8.2 \mathrm{~Hz}, \mathrm{H}-2^{\prime} / 6^{\prime}\right), 7.13(2 \mathrm{H}$, d, $\left.J=8.2 \mathrm{~Hz}, \mathrm{H}-3^{\prime} / 5^{\prime}\right), 2.43\left(2 \mathrm{H}, \mathrm{t}, J=6.7 \mathrm{~Hz}, \mathrm{H}-7^{\prime}\right), 3.01$ $\left(2 \mathrm{H}, \mathrm{t}, J=6.7 \mathrm{~Hz}, \mathrm{H}-8^{\prime}\right), 7.04$ (1H, OH-9').

\section{Bioassays}

The antimicrobial activity of the crude dichloromethane extract and its column fractions were determined by the disc diffusion method. ${ }^{8-10}$ The samples were dissolved separately in chloroform and applied to sterile filter paper discs at a concentration of $300 \mu \mathrm{g} /$ disc. Amoxicillin $(30 \mu \mathrm{g} / \mathrm{disc})$ was used as standard in each study. Discs containing the test materials were placed on nutrient agar medium, uniformly seeded with the test microorganisms. The plates were then incubated at $37{ }^{\circ} \mathrm{C}$ for 24 hours to allow maximum growth of the organisms. The test materials having antimicrobial activity inhibited the growth of the microorganisms and a clear, distinct zone of inhibition was visualized surrounding the disc. The antimicrobial activity of the test agents was determined by measuring the diameter of zone of inhibition in millimeter.

DMSO solutions of the plant crude extract and its fractions were assayed for cytotoxicity against Artemia salina in one day in vivo assay. ${ }^{11}$ For the experiment, $4 \mathrm{mg}$ of dichloromethane extract and each of the fractions was dissolved in DMSO and solutions of varying concentrations such as $400,200,100,50,25,12.50,6.25,3.125,1.563$, $0.781 \mu \mathrm{g}-\mathrm{mL}^{-1}$ were obtained by serial dilution technique. Then the solutions were added to the premarked vials containing ten live brine shrimp nauplii in $5 \mathrm{~mL}$ simulated sea water. After 24 hours, the vials were inspected using a magnifying glass and the number of survived nauplii in each vial was counted. The lethal concentration $\mathrm{LC}_{90}$ of the test samples after $24 \mathrm{hrs}$ was obtained by a plot of percentage of the shrimps killed against the logarithm of the sample concentration. Here, vincristine sulphate was used as the standard.

\section{Results and Discussion}

9'-Desmethylgaruganin I was isolated from dichloromethane extract of the stem bark of Garuga pinnata by repeated chromatographic separation and purification over silica gel. The structure of the isolated compound was determined by ${ }^{1} \mathrm{H}$ NMR data analysis as well as by comparison with previously reported values. ${ }^{12}$

The ${ }^{1} \mathrm{H}$ NMR spectrum of the compound showed a complex second order splitting pattern in the region of $\delta$ 2.34$3.01(8 \mathrm{H})$. The signals were located at $\delta 2.34(2 \mathrm{H}, \mathrm{m}), 2.43$ $(2 \mathrm{H}, \mathrm{t}, J=6.7 \mathrm{~Hz}), 2.86(2 \mathrm{H}, \mathrm{m}), 3.01(2 \mathrm{H}, \mathrm{t}, J=6.7 \mathrm{~Hz})$ which were assigned to the C-7, C- ${ }^{\prime}, \mathrm{C}-8$ and $\mathrm{C}$ $8^{\prime}$ methylene group protons, respectively.

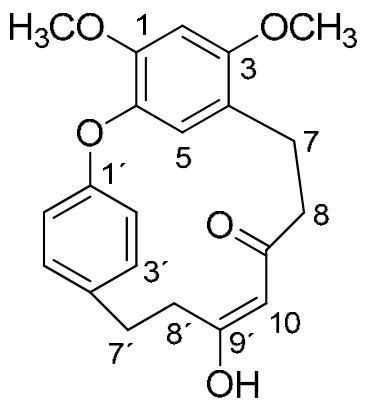

Fig.1. Structure of $9^{\prime}$-desmethylgaruganin I

The signals for two methoxyl groups appeared at $\delta 3.75$ $(3 \mathrm{H}, \mathrm{s})$ and $3.95(3 \mathrm{H}, \mathrm{s})$ were assigned for the two methoxyl groups at $\mathrm{C}-1$ and $\mathrm{C}-3$, respectively. A singlet at $\delta 4.94(1 \mathrm{H}$, s) corresponded to the proton attached to the $\alpha$-carbon $(\mathrm{C}$ $10)$ of the $\alpha, \beta$-unsaturated carbonyl group. The aromatic region of the ${ }^{1} \mathrm{H}$ NMR spectrum extended from $\delta$ 5.60-7.13 $(6 \mathrm{H})$. The signals at $\delta 6.97$ and $\delta 7.13(2 \mathrm{H}, \mathrm{d})$ were assigned to a para-substituted benzene ring protons in view of the coupling constant $(\mathrm{J}=8.2 \mathrm{~Hz})$. The two singlets at $\delta 5.63$ $(1 \mathrm{H}, \mathrm{s})$ and $\delta 6.50(1 \mathrm{H}, \mathrm{s})$ were ascribed to the tetrasubstituted benzene ring protons of $\mathrm{H}-5$ and $\mathrm{H}-2$, respectively. The proton at $\delta 5.63$ (H-5) was heavily shielded due to the anisotropic effect of the carbonyl group. The broad singlet at $\delta 7.04$ could be tentatively assigned for the hydroxyl group at C- $9^{\prime}$. This spectrum was very similar to that of the ${ }^{1} \mathrm{H}$ NMR spectrum of garuganin $\mathrm{I}$ in which there are three methoxyl groups instead of two ${ }^{13}$ but the spectrum of the compound found is identical to the hydrolyzed product of garuganin in which one hydroxyl group is present at C-9' . From the above spectral data and by comparing this data with those published for related compounds, the structure of the compound was elucidated as $9^{\prime}$-desmethylgaruganin I. A literature survey revealed that the compound is novel natural macrocyclic biphenyl ether. 
The result of the antimicrobial activities of crude dichloromethane and its column fractions of Garuga pinnata has been summarized in Table 1. Present investigation showed that only Fraction-8 has the moderate sensitivity against all the bacteria and fungi (except,
Aspergillus Niger), whereas the crude dichloromethane extract, Fraction-3 and Fraction-4 did not show any antimicrobial activity. The average zones of inhibition produced by Fraction- 8 were found to be $7-10 \mathrm{~mm}$ at a concentration of $300 \mu \mathrm{g} / \mathrm{disc}$.

Table 1. Antimicrobial activity of Garuga pinnata extracts (300 $\mathrm{\mu g} / \mathrm{disc})$ and Amoxicillin (30 $\mathrm{\mu g} / \mathrm{disc})$

\begin{tabular}{lccccc}
\hline \multirow{2}{*}{ Test Microorganisms } & \multicolumn{5}{c}{ Diameter of zone of inhibition (mm) } \\
\cline { 2 - 5 } Gram positive bacteria & DCM & Fraction-3 & Fraction-4 & Fraction-8 & AMOX \\
\hline Bacillus cereus & NA & NA & NA & 8 & 33 \\
Bacillus megaterium & NA & NA & NA & 7 & 35 \\
Staphylococcus aureus & NA & NA & NA & 9 & 33 \\
Sarcina lutea & NA & NA & NA & 8 & 12 \\
Gram negative bacteria & & & & & 20 \\
Escherichia coli & NA & NA & NA & 8 & 10 \\
Pseudomonas aeruginosa & NA & NA & NA & 8 & 15 \\
Salmonella paratyphi & NA & NA & NA & 10 & 14 \\
Salmonella typhi & NA & NA & NA & 10 & NA \\
Shigella boydii & NA & NA & NA & 9 & 20 \\
Shigella dysenteriae & NA & NA & NA & 9 & 25 \\
Vibrio mimicus & NA & NA & NA & 9 & 12 \\
Vibrio parahemolyticus & NA & NA & NA & 8 & NA \\
Fungi & & & & & NA \\
Candida albicans & NA & NA & NA & 10 & 15 \\
Aspergillus Niger & NA & NA & NA & NA & 9 \\
Sacharomyces cerevacae & NA & NA & NA & 9 & \\
\hline
\end{tabular}

DCM: dichloromethane extract; AMOX: Amoxicillin NA: No Activity

Fraction-8 showed the highest sensitivity against Salmonella paratyphi, Salmonella typhi and Candida albicans $(10 \mathrm{~mm})$ among all the bacteria and fungi, which is comparable to the standard amoxicillin and even showed the better potentiality against Candida albicans.

On the other hand, following the procedure of Meyer ${ }^{11,13}$, the lethality of crude dichloromethane extract and its fractions were screened by brine shrimp lethality bioassay for probable cytotoxic activity. The $\mathrm{LC}_{90}$ obtained from the best-fit line slope were found to be 25.703, 20.417, 16.595, 19.592 and $0.33 \mu \mathrm{g}-\mathrm{mL}^{-1}$ for dichloromethane extract, Fraction-3, Fraction-4, Fraction- 8 and vincristine sulphate (Std.), respectively cited in Table 2 . In comparison with the positive control (vincristine sulphate), the cytotoxicity exhibited by fraction- 4 was significant.

\section{Conclusion}

The present bioassay investigation showed that the stem bark of Garuga pinnata has mild to moderate antimicrobial and cytotoxic activities. In the present study, we have also isolated 9'-desmethylgaruganin I from the dichloromethane extract and further bioactivity guided chemical investigations are required to isolate the molecules that are responsible for bioactivities.

Table 2. $\mathrm{LC}_{90}$ data of Garuga pinnata. extracts

\begin{tabular}{ll}
\hline Samples & $\mathbf{L C}_{\mathbf{9 0}}(\boldsymbol{\mu g} / \mathbf{m L})$ \\
\hline VS & 0.33 \\
DCM & 25.703 \\
Fraction-3 & 20.417 \\
Fraction-4 & 16.595 \\
Fraction-8 & 19.592 \\
\hline
\end{tabular}

The values of $\mathrm{LC}_{90}$ are expressed in $\mu \mathrm{g} / \mathrm{ml}$.

DCM: dichloromethane extract 


\section{Acknowledgement}

The authors wish to thank the Bangladesh Council of Scientific and Industrial Research under Ministry of Science and Information and Communication Technology, Government of the Peoples' Republic of Bangladesh.

\section{References}

1. Ghani, A., 1998. Medicinal Plants of Bangladesh: Chemical Constituents and Uses, $2^{\text {nd }}$ edition, Asiatic Society of Bangladesh. 239.

2. Huq, A.M. and H. Hasan, 1987. Flora of Bangladesh. Bangladesh National Herbarium. 4.

3. Chopra, R.N., S.L. Nayar and I.C. Chopra, 1959. Glossary of Indian Medicinal Plants. CSIR, New Delhi, 123.

4. Yusuf, M., J.U. Chowdhury, M.A. Wahab, and J. Begum, 1994. Medicinal Plants of Bangladesh, BCSIR Laboratories, Chittagong, 112-114.

5. Ansari, F.R., W.H. Ansari and W. Rahman, 1978. A bi flavone from Garuga pinnata Burseraceae. Ind. J. Chem., Sec. B: Org. Chem. including Med. Chem., 16(9), 846-850.

6. Venkatraman, G., P.S. Thombone and B.K. Sabata, 1993. Chemical Abstracts, 118, 120948a.

7. Ara, K., A.H.M.M. Rahman, C.M. Hasan, M.N. Iskander, Y. Asakawa, N.D. Quang and M.A. Rashid, 2006. Macrocyclic diarylheptanoids from Gariga pinnata. Phytochemistry, 67, 2659-2662.
8. Bauer, A.W., W.M.M. Kirby, J.C. Sherris and M. Turck, 1966. Antibiotic susceptibility testing by a standardized single disc method. Am. J. Clin. Pathol., 45, 493-496.

9. Gazi, H.R., S. Kabir, M.S. Rahman, A.M.S. Chowdhury, B. Begum and M.A. Rashid, 2007. Antimicrobial and cytotoxic activities of the crude extracts of Hopea scaphula. Dhaka Univ. J. Pharm. Sci., 6(2), 131-133.

10. Siddiqi, M. M. A., M. D. Hossain, M. A. Al-Mansur, M. H. Sohrab, A.M.S. Chowdhury and C. M. Hasan, 2009. Antimicrobial and cytotoxic activities of the crude extracts of Spilanthes acmella. Dhaka Univ. J. Sci., 57(2), 215-216.

11. Bauer, A.W., W.M.M. Kirby, J.C. Sherris and M. Turck, 1966. Antibiotic susceptibility testing by a standardized single disc method. Am. J. Clin. Pathol., 45, 493-496.

12. Mishra, A.K., M.M. Haribal and B.K. Sabata, 1985. Photochemistry, 24(10), 2463-2465.

13. Morales, G., P. Sierra, A. Mancilla, A. Paredes, L.A. Loyola, O. Gallardo and J. Borquez, 2003. Secondary metabolites from four medicinal plants from northern Chile: antimicrobial activity and biotoxicity against Artemia salina. J. Chil. Chem. Soc., 48, 13-18. 